\title{
Monetary and Financial Instability and European Bank Interest Margins
}

\author{
Margarida Abreu \\ ISEG-Universidade de Lisboa, UECE and REM \\ Lisbon, Portugal \\ Victor Mendes \\ CMVM-Portuguese Securities Commission and CEFAGE-UE \\ Lisbon, Portugal
}

Received: March 21, 2018

Accepted: April 3, $2018 \quad$ Published: April 13, 2018

doi:10.5296/ifb.v5i1.13000

URL: http://dx.doi.org/10.5296/ifb.v5i1.13000

\begin{abstract}
This paper studies the extent to which financial instability and monetary and exchange rate policy influence European bank net interest margins, controlling for microeconomic variables and allowing for the heterogeneity of the banking industry. The sample is a broad cross-section of balance sheet and income statement information provided by banks from 12 European countries.

We conclude that European banks are sensitive to exchange rate and interest rate volatility. They are also affected by their home country's vulnerability to balance of payment and currency crises, but we find that banks feel differently about the associated risk of liquidity problems depending on their specialization. The instability of international financial markets is not good for banks, insofar as interest and exchange rate volatility both have a negative impact on the net interest margin.
\end{abstract}

Keywords: Monetary policy, Exchange rate policy, Banking, Net interest margins 


\section{Introduction}

This paper studies bank's sensitivity to monetary policy, exchange rates, and financial instability in developed markets. We look at the determinants of net interest margins (NIM) in European banks and analyze how these margins were affected by the EMS exchange rate crisis of the early nineties and the steps taken by monetary authorities to manage the crisis.

Banks collect, distribute and invest a large fraction of society's savings. The efficiency with which banks mediate capital allocation has an enormous impact on the economy. Despite the rising importance of fee-based income, a bank's interest margin remains one of its main sources of revenue.

One can look at NIM as an indicator of performance. NIM focuses on the traditional lending and borrowing operations of a bank; as such, NIM also reflects the cost of bank financing for firms, and determines the range of investment projects they will find profitable. In short, economic growth is influenced.

Empirical literature has analysed the determinants of financial crises, particularly in underdeveloped markets. Despite the generally accepted idea that crises have a negative influence on such economies, few authors have studied their influence on the banking industry itself. To the best of our knowledge, no one has yet analyzed the impact of crises on bank performance in well-developed financial markets.

We address this question, and attempt to determine the mechanisms by which periods of financial distress can generate banking problems. It is expected that crises in the financial sector could have a strong adverse impact on banks and the economy. Moreover, very little is known about the impact of public policy on banks during periods of crisis. In particular, we study whether monetary policy and exchange rate management have a discernable impact on bank performance.

This paper fills a gap in our knowledge that is becoming central to many financial discussions. For example, we witnessed some of the wildest trading days on record in August/September 2007. Several financial firms, including investment houses, hedge funds, mutual funds and banks, have been having problems. Even though the European mortgage market has different characteristics, the risk of this activity was widely spread and contagion has escalated. The credit market has reacted by freezing up and tightening credit conditions, which is likely to have slow down the economy.

Monetary and financial authorities are now, as at the time of the EMS financial crisis, facing a dilemma. On the one hand, there is a desire to boost liquidity (by injecting massive amounts of cash into the financial system) and prop up the economy. On the other hand, cutting interest rates doesn't necessarily fix the problem (of sub-prime debt or of exchange rate policy lack of credibility) and may eventually increase moral hazard problems. How much damage the crisis ultimately inflicts on bank profitability will depend on many factors, but the way financial and monetary authorities choose to manage the crisis is one of the most important. 
This paper follows in the footsteps of other papers on bank NIMs, extending their analysis in some relevant aspects. Firstly, we introduce a new macro dimension among the determinants of NIM. We evaluate whether European countries sharing a common bond-EMS membership - also share similar interest margin determinants. Secondly, we evaluate whether financial liberalization, monetary policy, exchange rate policy and periods of exchange rate turmoil can be accepted as explanatory variables for NIM. Thirdly, we allow for heterogeneity of the banking industry, and assess whether sensitivity to shocks varies across different types of banks on the basis of product specialization. Finally, we allow for the possibility that banks of different sizes may deliver their services using different technologies; their sensitivity to shocks may vary accordingly.

This paper makes three important contributions. First, we show that both bank size and specialization matter: the NIM determinants of commercial banks differ significantly from those of investment, mutual, savings, and real estate banks. Moreover, the NIM of commercial banks also respond differently to those determinants held in common with the other types, depending upon bank size. These results are robust under an array of sensitivity checks.

Second, we add to the existing literature on financial crises by presenting evidence on the impact of exchange rate crises in well-developed financial markets. As mentioned before, most studies of financial crises focus on small, recent, or less-developed markets; very little is known about the efficiency and performance of banks during and after a financial crisis in developed markets. By analysing data from EMS countries, we take steps towards filling this gap.

Finally, our results are of major relevance to economic policy. We show that monetary and exchange rate policies have a direct influence on the ability of banks to realize profits from the intermediation activity, and therefore affect the efficiency and stability of financial markets. Bank's NIM is not only sensitive to the credibility of exchange rate agreements, but also to the monetary policy implemented during a crisis. In a time of worries over a possible international financial crisis, this is a very useful result for regulatory policymakers. This paper highlights the fact that the behaviour of monetary authorities during periods of turmoil will have consequences on bank performance.

The paper is organized as follows. Section 2 provides some background and describes the methodology. Section 3 discusses the data and variables. Our results are presented in section 4 , and section 5 concludes.

\section{Background and Methodology}

The usual starting point of the study of NIM is the dealership model of Ho \& Saunders (1981). Both this paper and Saunders \& Schumacher (2000) model interest rate spreads in the bank credit market. These models have since been extended in several directions. Allen (1988) improved on the Ho \& Saunders (1981) model by allowing different types of credits and deposits. Wong (1997) and Angbazo (1997) developed a model with both credit risk and interest rate risk. Demirguç-Kunt \& Huizinga studied the effects of various determinants 
(1999) and financial development (2000) on NIM. Angelini \& Cetorelli (2003) assessed the impact of regulatory reforms on the structure of the Italian banking industry. Demirguç-Kunt et al. (2004) looked at the impact of bank regulations, market structure, and institutions. Maudos \& Guevara (2004) expanded the Ho \& Saunders (1981) model by taking a bank's operating costs explicitly into account. Hanweck \& Ryu (2005) developed a dynamic model of bank behaviour that explains NIM changes for different groups of banks in response to credit, interest-rate, and term-structure shocks. More recently, Carbó-Valverde \& Fernández (2007) applied the Ho \& Saunders (1981) model to a multi-output framework, Lin et al. (2012) study the determinants of NIM and their impact on bank diversification, Entrop et al. (2015) analyse the extent to which interest risk exposure is priced into bank margins, and Islam \& Nishiyama (2016) study the determinants of NIM in four South Asian countries.

This paper follows in the footsteps of this research, estimating several specifications of equation (1):

$$
\Pi_{i j t}=\beta_{0}+\beta_{l} B_{l i j t}+\beta_{m} X_{m j t}+\beta_{k} C_{k j t}+u_{i j t}
$$

The net interest margin- $\left[\Pi_{i j t}\right]$ for bank $i$ in country $j$ at time $t$ is explained by a vector $\left[\mathrm{B}_{i j t}\right]$ of micro characteristics specific to each bank, country, and time, a vector $\left[\mathrm{X}_{j t}\right]$ of policy and crisis variables specific to each country or groups of countries, controlling for a standard set of explanatory variables $\left[\mathrm{C}_{j t}\right]$ relevant to each country $j$ at time $t$, along with variables taking account of cross-country differences in the regulatory environment in which banks operate.

Some have claimed that the relationship between explanatory and explained variables is not linear (e.g., Swamy et al., 1996). Research on the US financial system has been consistent with the hypothesis that bank size is relevant (DeYoung et al., 2004). Banks of different sizes may use different technologies in the production and delivery of products and services. Large banks are more likely to make hard-information-based transactions, loaning money only to larger, safer, and more transparent borrowers. Small banks tend to deliver soft-information, relationship-based loans to smaller, riskier, and more opaque borrowers (Berger et al., 2004). In spite of these findings, very few have directly examined the effect of size on NIM (e.g. Angbazo, 1997; Hanweck \& Ryu, 2005). Here, we control for size, bank specialization, and non-linearity of the relationship.

\section{Data Set and Variable Definition}

\subsection{Data Set}

Bank-level information for 12 European countries (Portugal, Spain, Belgium, the Netherlands, France, Italy, Germany, the United Kingdom, Denmark, Finland, Sweden and Norway) covering the years 1988 to 1998 is from the Bankscope database, provided by Fitch-IBCA. (Note 1) Unlike other studies (Demirguç-Kunt et al., 2004; Barth et al., 2003; Demirguç-Kunt \& Huizinga, 1999), we do not average the data over this period. Instead we use annual data, because we want to test the impact of critical time-dependent macro financial variables on bank margins. We thereby obtain time-series coverage of certain variables at the expense of not smoothing others. (Note 2) 


\section{Macrothink}

International Finance and Banking

ISSN 2374-2089

2018, Vol. 5, No. 1

Information on macro variables is from the European Commission. (Note 3) Regulatory and institutional data is from the Barth et al. (2001) database and the World Bank (2003). Other sources of information are OECD, IMF, Datastream, Bloomberg, the Heritage Foundation and Bank of Portugal. Details on the sources and variable definitions are provided in the Appendix.

Overall, we have 25,676 bank-year-country observations. Our analysis is conducted on the level of individual banks. (Note 4) However, some observations are lost because not all information is available for the bank-specific variables. Moreover, aberrant data for individual banks are also excluded. We end up with 5,752 observations for commercial banks and 14,382 observations for savings, investment, real estate and cooperative banks. All countries are reasonably represented (Table 1), particularly in the commercial bank sample; however, the sample is more complete for recent years (Table 2).

Table 1. Number of observations from each country

\begin{tabular}{|l|l|l|l|}
\hline Country & Commercial Banks & Non Commercial Banks & All Banks \\
\hline Portugal & 136 & 38 & 174 \\
\hline Spain & 654 & 599 & 1,253 \\
\hline Belgium & 275 & 228 & 503 \\
\hline Netherlands & 132 & 23 & 155 \\
\hline France & 1,586 & 792 & 2,378 \\
\hline Italy & 837 & 2,204 & 3,041 \\
\hline Germany & 1,287 & 9,728 & 11,015 \\
\hline United Kingdom & 183 & 107 & 290 \\
\hline Denmark & 437 & 481 & 918 \\
\hline Finland & 57 & 9 & 66 \\
\hline Sweden & 55 & 31 & 86 \\
\hline Norway & 113 & 142 & 255 \\
\hline Total & 5,752 & 14,382 & 20,134 \\
\hline
\end{tabular}

Table 2. Number of observations in each year

\begin{tabular}{|l|l|l|l|}
\hline Year & Commercial Banks & Non Commercial Banks & All Banks \\
\hline 1988 & 195 & 107 & 302 \\
\hline 1989 & 210 & 107 & 317 \\
\hline 1990 & 218 & 171 & 389 \\
\hline 1991 & 305 & 264 & 569 \\
\hline 1992 & 525 & 682 & 1,207 \\
\hline 1993 & 701 & 1,653 & 2,354 \\
\hline 1994 & 781 & 2,003 & 2,784 \\
\hline 1995 & 693 & 2,104 & 2,797 \\
\hline 1996 & 723 & 2,250 & 2,973 \\
\hline 1997 & 720 & 2,437 & 3,157 \\
\hline 1998 & 681 & 2,604 & 3,285 \\
\hline Total & 5,752 & 14,382 & 20,134 \\
\hline
\end{tabular}




\subsection{The Dependent Variable}

Our dependent variable is NIM (interest income minus interest expenses, divided by the average value of all interest-bearing assets), a measure of ex-post bank performance. We split the sample by bank specialization: commercial and non-commercial banks. There is empirical evidence supporting the idea that banks with different product-line specializations have distinctive business models. Different types of banks also face different competitive environments, meaning that certain small organizations may earn monopolistic rents by competing in a particular market niche. Thus, bank portfolios associated with different specializations will probably exhibit different degrees of sensitivity to the various explanatory variables.

\subsection{Independent Variables}

\subsubsection{Bank-Specific Control Variables}

We use bank-specific variables to control for any differences that might obscure the impact of monetary policy, exchange rate policy, and exchange rate crises. If the banking industry exhibits increasing returns to scale, for example, then size is an important determinant of NIM and profitability. Empirical studies in banking have generally concluded that slight economies of scale do exist, and that the relationship is not linear. We therefore use the logarithm of total bank assets as an explanatory variable to capture this effect (e.g., Demirguç-Kunt et al., 2004). (Note 5)

Different bank's product lines may also influence its pricing of loans. When a bank's fee-generating activities are well developed it may choose to cross-subsidize lending activities, thereby lowering interest margins. In order to reduce potential simultaneity problems of this nature, we include the following variables: OFF1 = 1 if a bank's off-balance items divided by its total earning assets is lower than 15\%; OFF2 = 1 if a bank's off-balance items divided by its total earning assets is greater than $15 \%$ but less than $40 \%$; OFF3 $=1$ if a bank's off-balance items divided by its total earning assets is greater than $40 \%$. (Note 6 )

Among the bank-specific variables we also include the Equity to Total Assets ratio (ETA), the Loans to Total Assets ratio (LTA), the Loan Loss Provisions to Gross Loan ratio (LLPGL), the Cost to Income ratio (CTI), the Total Earning Assets to Total Assets ratio (TEATA) and the bank's Market Share (MS).

We expect that a higher ETA will reduce the need for external funding, and therefore lead to higher NIM. Well-capitalized banks also face a lower cost of going bankrupt, so the cost of their funding is reduced. In order to lessen potential simultaneity problems, we divide ETA into the following variables: ETA1 $=1$ if ETA is less than 5\%; ETA2 $=1$ if ETA is greater than $5 \%$ but less than $10 \%$; ETA3 $=1$ if ETA is greater than $10 \%$. (Note 7 )

The LTA ratio reflects the "traditionalism" of a bank's activities. Banks serve as intermediaries between lenders and borrowers. Everything else constant, NIM will be higher when more deposits are transformed into loans. If a bank needs to incur higher risk in order to have a higher LTA, the margin also increases. But in a competitive environment, where the 


\section{Al Macrothink}

bank faces a pool of customers with identical risk, it will need to decrease the interest charged on loans and accept a lower NIM.

The LLPGL ratio is a proxy for risk. If a bank operates in riskier environments and/or lacks the expertise to control its lending operations, then the LLPGL ratio is higher. Ideally, banks should have higher NIM to compensate for this risk (and the concomitant perceived future loan losses).

The cost-to-income ratio is a proxy for management quality/efficiency. If a manager is able to apply the bank's assets more efficiently (e.g., by finding a more profitable composition of assets and lowering the cost of funding), then this will be reflected in higher NIM.

The total earning assets to total assets ratio (TEATA) is another important control variable. If a bank is able to transform its assets into more profitable applications, then higher interest margins are expected. But if the transformation is inefficient, either because the bank lacks expertise or because it needs to forego income from more traditional activities, then the NIM may decrease instead.

Banks with larger market shares (MS) may exercise market power and thus enjoy higher NIM. However, this relationship could be reversed if bank products are highly differentiated and market demand is small relative to bank size. (Note 8)

Quadratic terms on continuous bank-specific variables are also included to account for possible non-linearity of these relationships.

Some characteristics of the bank-level sample are presented in Tables 3 and 4 . There are some extreme values among the data, for example the max/min figures for CTI and LLPGL. The sensitivity of our results to these extreme values is discussed in Section 4. As for the three classes defined for off-balance activity and equity ratio, each one contains a reasonable number of observations (Table 3). Other definitions of these classes were tested; the results are robust to variations in the limiting values, and are therefore not reported (see Notes 6 and 7).

Table 3. Number of observations in each class

\begin{tabular}{|l|l|l|l|}
\hline & Commercial Banks & Non Commercial Banks & All Banks \\
\hline ETA1 & 1,775 & 8,122 & 9,897 \\
\hline ETA2 & 2,357 & 4,328 & 6,685 \\
\hline ETA3 & 1,620 & 1,929 & 3,549 \\
\hline OFF1 & 1,005 & 4,212 & 5,217 \\
\hline OFF2 & 1,786 & 7,888 & 9,674 \\
\hline OFF3 & 2,961 & 2,278 & 5,239 \\
\hline
\end{tabular}


Table 4. Bank-level sample statistics

\begin{tabular}{|l|r|r|r|r|r|r|r|r|r|r|}
\hline & \multicolumn{4}{|c|}{ Commercial Banks } & \multicolumn{5}{|c|}{ Non-Commercial Banks } \\
\cline { 2 - 10 } \multicolumn{1}{r|}{$\%$} & Mean & Median & \multicolumn{1}{c|}{ Max } & \multicolumn{1}{c|}{ Min } & S. D. & Mean & Median & \multicolumn{1}{c|}{ Max } & Min & \multicolumn{1}{c|}{ S. D. } \\
\hline CTI & 70.3 & 69.1 & 283.3 & -190.3 & 27.4 & 66.8 & 66.7 & 296.4 & -177.5 & 15.1 \\
LTA & 46.9 & 46.8 & 99.7 & 0.0 & 22.9 & 57.5 & 60.4 & 99.6 & 0.1 & 15.7 \\
LLPGL & 1.6 & 0.8 & 74.3 & -89.4 & 5.3 & 0.8 & 0.6 & 63.6 & -56.8 & 1.5 \\
TEATA & 93.2 & 94.4 & 100.0 & 25.6 & 5.9 & 94.5 & 95.3 & 100.0 & 33.8 & 3.5 \\
MS & 0.9 & 0.1 & 44.6 & 0.0 & 3.2 & 0.2 & 0.0 & 35.0 & 0.0 & 1.0 \\
TA $(*)$ & 57.7 & 6.6 & 4476.1 & 0.0 & 214.7 & 17.7 & 3.8 & 1438.7 & 0.0 & 56.9 \\
\hline
\end{tabular}

Note. *billion euro, 1994 constant prices.

\subsubsection{Domestic Regulatory and Macroeconomic Variables}

Bank concentration (CR5) is equal to the fraction of bank assets held by the five largest banks in the country, computed using bank-level data from the Bankscope database. (Note 9) Higher concentrations have been interpreted as indicative of lower competition, and one should expect a positive relationship between concentration and NIM. But this share is also a measure of the relevant market for larger banks, which may behave differently from smaller banks. Ho \& Saunders (1981), for example, have shown that larger banks have lower spreads.

We use the variables BFR, AREST and ST to control for the regulatory environment. BFR is an indicator of banking freedom averaged over the 1995-99 period. It ranges from 1 to 5, with larger values meaning more freedom. The activity restrictions (AREST) variable measures two factors: (1) a bank's ability to engage in securities underwriting, insurance, and real estate, and (2) the strength of regulatory restrictions on shares owned in non-financial firms. Its value ranges between one and four, higher values mean stronger restrictions. We expect that tighter restrictions deteriorate competitive market conditions, and tend to raise NIM. If banks are not permitted to compete in every aspect of their business, then their risk will be concentrated in a smaller array of products and services and the banks will need to charge higher margins. However, some institutions may have difficulty managing products and services outside the scope of traditional banking activities; this effect could lead to lower NIM. Also, the existence of strong financial innovations will diminish such banks' advantage with respect to fund collection. Traditional banks will therefore need to either increase passive rates in order to attract funds away from their innovative competitors, or decrease lending rates to retain their clients. Both solutions will have a negative effect on NIM.

ST indicates the development of the stock market. It is defined as the volume of stocks traded as a percentage of the GDP. There are two conflicting views on its likely effect. On the one hand, countries with more developed stock markets may have a more competitive banking environment that exerts downward pressure on net interest margins (Demirguç-Kunt et al., 2004). On the other hand, there is empirical evidence that the ability of firms to attract equity capital may also increase their borrowing capacity (Demirguç-Kunt \& Maksimovic, 1996). In the latter case, increasing debt financing could lead to higher margins.

Among domestic macroeconomic variables, we include real GDP growth (GDPG), GDP per 
capita (GDPPC), the inflation rate (INF), and the unemployment rate (UR). Adverse macroeconomic conditions hurt banks by increasing the share of non-performing loans in the economy; all firms are in greater danger of failure during bad times, particularly recessions. Low or declining aggregate growth rates may also weaken the debt servicing capacity of domestic borrowers, increasing the credit risk. Such an increase in risk could be compensated by higher spreads, and we would also expect a decrease in the real growth of GDP to increase net interest margins. Putting it differently, an increase in economic activity is expected to raise the net worth of borrowers and lower spreads (Bernanke \& Gertler, 1989). The unemployment rate offers similar arguments.

GDP per capita is used as a general indicator of institutional development. It is very difficult to measure the importance of having well-functioning institutions to bank margins, but we expect that a high GDPPC is a good proxy for financial competition and thus lower bank margins. Another possible explanation is as follows: in a context of well-functioning institutions, particularly for whatever activities concern the rule of law (contract enforcement), we expect a reduction of default risk and/or increased recovery in the event of default. Hence, this environment leads to a reduction in the cost of the bank's financial mediation role. However, even in a good institutional environment low-grade borrowers could easily tap the credit market at the expense of a higher average interest rate on loans (Demirguç-Kunt et al., 2004; Laeven \& Majnoni, 2005).

High inflation is associated with high nominal interest rates, and may also be viewed as a proxy for poor macroeconomic management. High inflation is also often associated with higher relative price volatility, which makes the accurate assessment of credit and market risks more difficult. But a significant and rapid reduction in the rate of inflation could lead to lower nominal income and cash flows, affecting the liquidity and solvency of financial institutions. On the other hand, if an inflation shock does not impact the active and passive rates equally rapidly, bank interest margins will be correlated with inflation. (Note 10) The risk of borrowing is likely to increase with increasing interest rates. Thus, the fact that banks will try to be compensated for higher risk yields a positive relationship between inflation and NIM.

\subsubsection{Policy and Macro-Financial Variables}

The real effective exchange rate (REER) is included in the model. Positive variation in this exchange rate means a real, effective appreciation of the currency. Large changes in the exchange rate could put pressure on a financial system in two ways: directly by changing asset values, or indirectly via possible effects on the real economy (Evans et al., 2000). Some groups of countries tend to follow very similar exchange rate strategies (the Nordic countries on the one hand, and Portugal, Spain and Italy on the other). Thus, we introduce NORD as a dummy variable for the Nordic countries and PTSPIT as a dummy variable for Portugal, Spain and Italy.

The current account balance as a percentage of GDP (BTC/GDP) measures the country's vulnerability to a currency crisis. Such a financial crisis may happen when investors consider the foreign deficit unsustainable, and start shifting their assets out of the country. This kind of 
crisis may cause significant liquidity problems in the country's financial system, especially if the deficit is financed by short-term capital inflows. We therefore associate growing deficits with worsening bank performance. If BTC/GDP increases, on the other hand, then capital inflows should increase as well. This could facilitate a credit boom, at the eventual expense of lower credit quality, with banks increasing their interest margins due to the concomitant increase in risk.

To test whether systemic banking sector problems are related to sudden capital outflows in countries with an exchange rate peg, we also introduce the ratio of M2 growth to the growth of foreign exchange reserves $(1+\mathrm{M} 2 \mathrm{G}) /(1+\mathrm{RESG})$. This ratio is a good predictor of a country's vulnerability to balance of payments crises (Calvo, 1996; Demirguç-Kunt \& Detragiache, 1997).

Domestic (NSTIR) and international short-term interest rates (ISTIR) are also considered. When international interest rates rise relative to domestic rates, the vulnerability of the financial system may increase through the channel of asset substitution: significant outflows of capital will cause a liquidity structural problem in the banking system. Banks need to increase deposit rates to fight back, lowering their interest margin. On the other hand, relatively low international interest rates may create disturbing capital inflows that could encourage a risky credit boom. Large interest rate differentials could therefore be associated with increasing information problems, particularly adverse selection. Hence, the excess liquidity would contribute to decreasing lending rates; information problems, however, would result in higher lending rates.

To measure the importance of financial market stability to bank performance, we include the volatilities of domestic interest rates (NSTIRV), international interest rates (ISTIRV), and domestic exchange rates against the mark (VOLDEMMN). Interest rate volatility slows down investment and hinders consumer confidence, both of which hinder GDP growth. Higher volatility levels thus increase the probability of a future recession, meaning that NIM should include a risk premium.

We include a dummy variable (DCFPS) to test the effect of financial liberalization. Financial liberalization promotes transparency and accountability, reducing the adverse selection and moral hazard problems via increasing financial markets liquidity (Mishkin, 2001; Kaminsky, 2003). However, in the short run capital controls may help, at least temporarily, by managing and smoothing the negative impact of a rapid retreat of foreign investors (Williamson, 2000). Indeed, the impact of financial liberalization on bank profitability is particularly important when associated with exchange rate turmoil or exchange rate market pressure. In such cases, allowing short-term capital movements may contribute to the instability of the foreign reserves flow and decrease the country's ability to peg its domestic currency. In the short run, capital outflows may cause some liquidity problems for banks. The maturity mismatch will be overcome by quick asset sales, with a negative impact on bank performance.

Portugal and Spain took their final step towards financial liberalization by legalizing short-term capital movements in 1992 and 1993 respectively. In the other countries of this study, all capital movements were already free by this time. Accordingly, the DCFPS variable 


\section{Mll Macrothink}

International Finance and Banking

ISSN 2374-2089

2018, Vol. 5, No. 1

is set to 1 if the country is Portugal and the year is 1992 or beyond, and if the country is Spain and the year is 1993 or beyond. (Note 11)

To capture the impact of the European Monetary System (EMS) crisis, we include one dummy variable: CRIS. The EMS crisis started in August 1992 and ended for most member countries in August 1993 with the widening of exchange rate bands. Portugal and Spain were exceptions: the Portuguese escudo remained under pressure until the final EMS realignment in March 1995. The CRIS variable is equal to 1 if the year is 1992 or 1993 (for all countries), and also if the year is 1994 and the country is Portugal or Spain.

\section{Results}

Equation 1 was estimated by weighted least squares, separately for commercial and non-commercial banks. (Note 12) Given that the number of banks in the sample varies widely across countries, the data for a given year are weighted by the inverse of the number of banks for the country. (Note 13) Our regressions include country- and year-fixed effects as well.

We use a step-wise method. First, we fit only the bank-specific, linear explanatory variables (column 1 in Tables 5 and 6). Then we include a set of country-specific regulatory and macroeconomic variables (column 2). Next, we add the policy variables (column 3). Fourth, we evaluate the impact of the EMS crisis (column 4). In column 5, we test for the possibility of non-linearity in continuous, bank-specific regressors. In column 6 we evaluate the impact of bank size on macro and regulatory variables. Finally, we test the effect of bank size on the crisis variables (column 7).

Furthermore, the Hausman exogeneity test was used to test the hypothesis that CTI, LTA, TEATA, and LLPL are exogenous variables. The data are consistent with exogeneity of these variables (the null hypothesis) at the $95 \%$ confidence level.

Table 5. Estimation results - commercial banks

\begin{tabular}{|l|l|l|l|l|l|l|l|}
\hline & 1 & 2 & 3 & 4 & 5 & 6 & 7 \\
\hline Log(TA) & -0.107 & -0.297 & -0.285 & -0.294 & -0.348 & 1.331 & 1.402 \\
\hline & $(0.000)$ & $(0.000)$ & $(0.000)$ & $(0.000)$ & $(0.000)$ & $(0.000)$ & $(0.000)$ \\
\hline OFF2 & -0.211 & -0.064 & -0.062 & -0.050 & -0.121 & -0.207 & -0.215 \\
\hline & $(0.000)$ & $(0.084)$ & $(0.091)$ & $(0.170)$ & $(0.001)$ & $(0.000)$ & $(0.000)$ \\
\hline OFF3 & -0.487 & -0.518 & -0.531 & -0.566 & -0.626 & -0.735 & -0.754 \\
\hline & $(0.000)$ & $(0.000)$ & $(0.000)$ & $(0.000)$ & $(0.000)$ & $(0.000)$ & $(0.000)$ \\
\hline ETA2 & 0.079 & 0.206 & 0.223 & 0.202 & 0.139 & 0.134 & 0.159 \\
\hline & $(0.045)$ & $(0.000)$ & $(0.000)$ & $(0.000)$ & $(0.000)$ & $(0.000)$ & $(0.000)$ \\
\hline ETA3 & 1.250 & 0.906 & 0.858 & 0.814 & 0.780 & 0.636 & 0.657 \\
\hline & $(0.000)$ & $(0.000)$ & $(0.000)$ & $(0.000)$ & $(0.000)$ & $(0.000)$ & $(0.000)$ \\
\hline CTI & -0.008 & -0.010 & -0.009 & -0.008 & -0.001 & -0.001 & +0.000 \\
\hline & $(0.000)$ & $(0.000)$ & $(0.000)$ & $(0.000)$ & $(0.391)$ & $(0.507)$ & $(0.849)$ \\
\hline CTI^2 & & & & & -0.000 & -0.000 & -0.000 \\
\hline & & & & & $(0.000)$ & $(0.000)$ & $(0.000)$ \\
\hline LTA & 0.011 & 0.011 & 0.011 & 0.011 & 0.043 & 0.047 & 0.047 \\
\hline & $(0.000)$ & $(0.000)$ & $(0.000)$ & $(0.000)$ & $(0.000)$ & $(0.000)$ & $(0.000)$ \\
\hline LTA^2 & & & & & -0.000 & -0.000 & -0.000 \\
\hline & & & & & $(0.000)$ & $(0.000)$ & $(0.000)$ \\
\hline
\end{tabular}




\begin{tabular}{|c|c|c|c|c|c|c|c|}
\hline \multirow[t]{2}{*}{ LLPGL } & 0.917 & 2.090 & 2.445 & 2.466 & 2.042 & 1.358 & 1.371 \\
\hline & $(0.143)$ & $(0.000)$ & $(0.000)$ & $(0.000)$ & $(0.000)$ & $(0.009)$ & $(0.008)$ \\
\hline \multirow[t]{2}{*}{$\mathrm{LLPGL}^{\wedge} 2$} & & & & & 3.564 & 3.081 & 3.515 \\
\hline & & & & & $(0.000)$ & $(0.001)$ & $(0.000)$ \\
\hline \multirow[t]{2}{*}{ TEATA } & -6.244 & -2.356 & -2.496 & -2.373 & 32.411 & 36.309 & 37.071 \\
\hline & $(0.000)$ & $(0.000)$ & $(0.000)$ & $(0.000)$ & $(0.000)$ & $(0.000)$ & $(0.000)$ \\
\hline \multirow[t]{2}{*}{ TEATA^2 $^{\prime}$} & & & & & -20.574 & -23.438 & -23.887 \\
\hline & & & & & $(0.000)$ & $(0.000)$ & $(0.000)$ \\
\hline \multirow[t]{2}{*}{$\mathrm{MS}$} & 0.022 & 0.025 & 0.022 & 0.022 & 0.046 & -0.040 & -0.041 \\
\hline & $(0.000)$ & $(0.000)$ & $(0.000)$ & $(0.000)$ & $(0.000)$ & $(0.000)$ & $(0.000)$ \\
\hline \multirow[t]{2}{*}{$\mathrm{MS}^{\wedge} 2$} & & & & & -0.001 & 0.000 & 0.000 \\
\hline & & & & & $(0.000)$ & $(0.040)$ & $(0.049)$ \\
\hline \multirow[t]{2}{*}{ CR5 } & & 0.018 & 0.020 & 0.019 & 0.021 & 0.022 & 0.021 \\
\hline & & $(0.000)$ & $(0.000)$ & $(0.000)$ & $(0.000)$ & $(0.000)$ & $(0.000)$ \\
\hline \multirow[t]{2}{*}{ CR5*Log(TA) } & & & & & & -0.001 & -0.000 \\
\hline & & & & & & $(0.322)$ & $(0.700)$ \\
\hline \multirow[t]{2}{*}{ AREST } & & 0.787 & -4.400 & -4.578 & -4.624 & -2.649 & -2.225 \\
\hline & & $(0.047)$ & $(0.000)$ & $(0.000)$ & $(0.000)$ & $(0.000)$ & $(0.006)$ \\
\hline \multirow[t]{2}{*}{ AREST*Log(TA) } & & & & & & -0.007 & -0.060 \\
\hline & & & & & & $(0.846)$ & $(0.141)$ \\
\hline \multirow[t]{2}{*}{ BFR } & & -1.228 & -5.053 & -5.147 & -4.942 & -2.525 & -2.218 \\
\hline & & $(0.001)$ & $(0.000)$ & $(0.000)$ & $(0.000)$ & $(0.000)$ & $(0.001)$ \\
\hline \multirow[t]{2}{*}{ BFR*Log(TA) } & & & & & & -0.298 & -0.325 \\
\hline & & & & & & $(0.000)$ & $(0.000)$ \\
\hline \multirow[t]{2}{*}{ ST } & & 0.020 & 0.017 & 0.015 & 0.011 & 0.016 & 0.017 \\
\hline & & $(0.000)$ & $(0.000)$ & $(0.000)$ & $(0.000)$ & $(0.000)$ & $(0.000)$ \\
\hline \multirow[t]{2}{*}{$\mathrm{ST}^{*} \log (\mathrm{TA})$} & & & & & & -0.002 & -0.003 \\
\hline & & & & & & $(0.000)$ & $(0.000)$ \\
\hline \multirow[t]{2}{*}{ DCFPS } & & -1.336 & -1.339 & -1.300 & -1.388 & -1.347 & -1.566 \\
\hline & & $(0.000)$ & $(0.000)$ & $(0.000)$ & $(0.000)$ & $(0.000)$ & $(0.000)$ \\
\hline \multirow[t]{2}{*}{ DCFPS $* \log (\mathrm{TA})$} & & & & & & -0.054 & -0.028 \\
\hline & & & & & & $(0.236)$ & $(0.549)$ \\
\hline \multirow[t]{2}{*}{ GDPG } & & 0.010 & -0.056 & -0.098 & -0.096 & -0.205 & -0.198 \\
\hline & & $(0.371)$ & $(0.000)$ & $(0.000)$ & $(0.000)$ & $(0.000)$ & $(0.000)$ \\
\hline GDPG*Log(TA) & & & & & & 0.031 & 0.026 \\
\hline & & & & & & $(0.000)$ & $(0.000)$ \\
\hline GDPPC & & -0.151 & -0.164 & -0.129 & -0.152 & -0.083 & -0.064 \\
\hline & & $(0.000)$ & $(0.000)$ & $(0.001)$ & $(0.000)$ & $(0.041)$ & $(0.121)$ \\
\hline GDPPC* $\log (\mathrm{TA})$ & & & & & & 0.002 & -0.004 \\
\hline & & & & & & $(0.703)$ & $(0.493)$ \\
\hline UR & & -0.048 & -0.120 & -0.159 & -0.177 & -0.026 & -0.012 \\
\hline & & $(0.000)$ & $(0.000)$ & $(0.000)$ & $(0.000)$ & $(0.250)$ & $(0.620)$ \\
\hline UR*Log(TA) & & & & & & -0.027 & -0.032 \\
\hline & & & & & & $(0.000)$ & $(0.000)$ \\
\hline INF & & -0.117 & -0.146 & -0.140 & -0.148 & -0.011 & -0.073 \\
\hline & & $(0.000)$ & $(0.000)$ & $(0.000)$ & $(0.000)$ & $(0.637)$ & $(0.003)$ \\
\hline INF* $\log (\mathrm{TA})$ & & & & & & -0.058 & -0.040 \\
\hline & & & & & & $(0.000)$ & $(0.000)$ \\
\hline NSTIRV & & -0.033 & 0.008 & -0.011 & 0.010 & 0.075 & 0.086 \\
\hline & & $(0.044)$ & $(0.648)$ & $(0.633)$ & $(0.659)$ & $(0.047)$ & $(0.029)$ \\
\hline NSTIRV*Log(TA) & & & & & & -0.053 & -0.065 \\
\hline & & & & & & $(0.000)$ & $(0.000)$ \\
\hline ISTIRV & & 1.828 & 0.678 & -1.860 & -2.058 & -2.030 & -2.259 \\
\hline & & $(0.000)$ & $(0.091)$ & $(0.027)$ & $(0.012)$ & $(0.011)$ & $(0.005)$ \\
\hline ISTIRV*Log(TA) & & & & & & -0.023 & 0.034 \\
\hline & & & & & & $(0.504)$ & $(0.357)$ \\
\hline
\end{tabular}




\begin{tabular}{|c|c|c|c|c|c|c|}
\hline NSTIR-ISTIR & 0.155 & 0.176 & 0.184 & 0.151 & 0.167 & 0.238 \\
\hline & $(0.000)$ & $(0.000)$ & $(0.000)$ & $(0.000)$ & $(0.000)$ & $(0.000)$ \\
\hline (NSTIR-ISTIR)*Log(TA) & & & & & 0.017 & -0.006 \\
\hline & & & & & $(0.001)$ & $(0.318)$ \\
\hline BTC/GDP & & 7.653 & 8.305 & 9.826 & 8.053 & 3.030 \\
\hline & & $(0.000)$ & $(0.000)$ & $(0.000)$ & $(0.000)$ & $(0.113)$ \\
\hline BTC/GDP*Log(TA) & & & & & & 1.634 \\
\hline & & & & & & $(0.001)$ \\
\hline$(1+\mathrm{M} 2 \mathrm{G}) /(1+\mathrm{RESG})$ & & 0.019 & 0.015 & 0.019 & 0.010 & -0.002 \\
\hline & & $(0.000)$ & $(0.001)$ & $(0.000)$ & $(0.017)$ & $(0.699)$ \\
\hline$(1+\mathrm{M} 2 \mathrm{G}) /(1+\mathrm{RESG}) * \log (\mathrm{TA})$ & & & & & & 0.005 \\
\hline & & & & & & $(0.015)$ \\
\hline REER & & -0.000 & -0.000 & -0.000 & -0.000 & -0.000 \\
\hline & & $(0.000)$ & $(0.189)$ & $(0.346)$ & $(0.228)$ & $(0.080)$ \\
\hline REER*Log(TA) & & & & & & 0.000 \\
\hline & & & & & & $(0.097)$ \\
\hline VOLDEMMN & & -0.157 & -0.273 & -0.248 & -0.176 & -0.240 \\
\hline & & $(0.000)$ & $(0.000)$ & $(0.000)$ & $(0.000)$ & $(0.000)$ \\
\hline VOLDEMMN*Log(TA) & & & & & & 0.025 \\
\hline & & & & & & $(0.036)$ \\
\hline REER*NORD & & & -0.000 & -0.000 & -0.000 & -0.000 \\
\hline & & & $(0.000)$ & $(0.000)$ & $(0.000)$ & $(0.000)$ \\
\hline REER*PTSPIT & & & 0.000 & -0.000 & -0.000 & -0.000 \\
\hline & & & $(0.568)$ & $(0.996)$ & $(0.914)$ & $(0.818)$ \\
\hline CRIS & & & -3.496 & -3.294 & -3.239 & -3.384 \\
\hline & & & $(0.000)$ & $(0.000)$ & $(0.000)$ & $(0.000)$ \\
\hline CRIS*Log(TA) & & & & & & 0.085 \\
\hline & & & & & & $(0.692)$ \\
\hline VOLDEMMN*CRIS & & & 0.068 & 0.061 & -0.009 & 0.039 \\
\hline & & & $(0.017)$ & $(0.031)$ & $(0.765)$ & $(0.546)$ \\
\hline VOLDEMMN*CRIS*Log(TA) & & & & & & -0.018 \\
\hline & & & & & & $(0.242)$ \\
\hline REER*CRIS & & & 0.000 & 0.000 & 0.000 & 0.000 \\
\hline & & & $(0.000)$ & $(0.000)$ & $(0.000)$ & $(0.019)$ \\
\hline REER*CRIS*Log(TA) & & & & & & 0.000 \\
\hline & & & & & & $(0.534)$ \\
\hline
\end{tabular}

Note. The values in parentheses are p-values.

Table 6. Estimation results - non-commercial banks

\begin{tabular}{|l|l|l|l|l|l|l|l|}
\hline & 1 & 2 & 3 & 4 & 5 & 6 & 7 \\
\hline $\log (\mathrm{TA})$ & -0.410 & -0.280 & -0.304 & -0.315 & -0.368 & -3.026 & -1.519 \\
\hline & $(0.000)$ & $(0.000)$ & $(0.000)$ & $(0.000)$ & $(0.000)$ & $(0.000)$ & $(0.000)$ \\
\hline OFF2 & -0.668 & -0.194 & -0.154 & -0.284 & -0.159 & -0.266 & -0.116 \\
\hline & $(0.000)$ & $(0.000)$ & $(0.000)$ & $(0.000)$ & $(0.000)$ & $(0.000)$ & $(0.000)$ \\
\hline OFF3 & -0.997 & -0.427 & -0.389 & -0.373 & -0.670 & -0.631 & -0.726 \\
\hline & $(0.000)$ & $(0.000)$ & $(0.000)$ & $(0.000)$ & $(0.000)$ & $(0.000)$ & $(0.000)$ \\
\hline ETA2 & 0.026 & -0.455 & -0.392 & -0.342 & -0.242 & -0.284 & -0.309 \\
\hline & $(0.310)$ & $(0.000)$ & $(0.000)$ & $(0.000)$ & $(0.000)$ & $(0.000)$ & $(0.000)$ \\
\hline ETA3 & 1.948 & 0.568 & 0.608 & 0.631 & 0.370 & 0.512 & 0.483 \\
\hline & $(0.000)$ & $(0.000)$ & $(0.000)$ & $(0.000)$ & $(0.000)$ & $(0.000)$ & $(0.000)$ \\
\hline CTI & 0.004 & 0.007 & 0.007 & 0.006 & 0.010 & 0.012 & 0.015 \\
\hline & $(0.000)$ & $(0.000)$ & $(0.000)$ & $(0.000)$ & $(0.000)$ & $(0.000)$ & $(0.000)$ \\
\hline CTI^2 & & & & & -0.000 & -0.000 & -0.000 \\
\hline & & & & & $(0.000)$ & $(0.000)$ & $(0.000)$ \\
\hline
\end{tabular}


MIMacrothink

International Finance and Banking

ISSN 2374-2089

2018, Vol. 5, No. 1

\begin{tabular}{|c|c|c|c|c|c|c|c|}
\hline \multirow{2}{*}{ LTA } & 0.006 & -0.002 & -0.003 & -0.002 & 0.115 & 0.115 & 0.118 \\
\hline & $(0.000)$ & $(0.001)$ & $(0.000)$ & $(0.002)$ & $(0.000)$ & $(0.000)$ & $(0.000)$ \\
\hline \multirow[t]{2}{*}{ LTA $^{\wedge} 2$} & & & & & -0.001 & -0.001 & -0.001 \\
\hline & & & & & $(0.000)$ & $(0.000)$ & $(0.000)$ \\
\hline \multirow[t]{2}{*}{ LLPGL } & 16.061 & 11.127 & 10.670 & 9.604 & 14.194 & 23.413 & 29.253 \\
\hline & $(0.000)$ & (0.000) & $(0.000)$ & $(0.000)$ & $(0.000)$ & $(0.000)$ & $(0.000)$ \\
\hline \multirow[t]{2}{*}{$\mathrm{LLPGL}^{\wedge} 2$} & & & & & -35.362 & -56.960 & -68.557 \\
\hline & & & & & $(0.000)$ & $(0.000)$ & $(0.000)$ \\
\hline \multirow[t]{2}{*}{ TEATA } & -3.725 & -3.502 & -3.257 & -3.317 & -5.777 & -10.527 & -14.676 \\
\hline & $(0.000)$ & $(0.000)$ & $(0.000)$ & $(0.000)$ & $(0.006)$ & $(0.000)$ & $(0.000)$ \\
\hline \multirow{2}{*}{ TEATA $^{\wedge} 2$} & & & & & 2.027 & 4.752 & 7.397 \\
\hline & & & & & $(0.108)$ & $(0.000)$ & $(0.000)$ \\
\hline \multirow[t]{2}{*}{ MS } & 0.179 & 0.164 & 0.170 & 0.173 & 0.309 & 0.081 & 0.086 \\
\hline & $(0.000)$ & $(0.000)$ & $(0.000)$ & $(0.000)$ & $(0.000)$ & $(0.000)$ & $(0.000)$ \\
\hline \multirow[t]{2}{*}{$\mathrm{MS}^{\wedge} 2$} & & & & & -0.010 & -0.004 & -0.004 \\
\hline & & & & & (0.000) & $(0.000)$ & $(0.000)$ \\
\hline \multirow[t]{2}{*}{ CR5 } & & -0.006 & -0.004 & -0.001 & 0.002 & -0.003 & -0.007 \\
\hline & & $(0.000)$ & $(0.000)$ & $(0.514)$ & $(0.014)$ & $(0.001)$ & $(0.000)$ \\
\hline \multirow[t]{2}{*}{ CR5*Log(TA) } & & & & & & 0.003 & 0.003 \\
\hline & & & & & & $(0.000)$ & $(0.000)$ \\
\hline \multirow[t]{2}{*}{ AREST } & & 1.438 & -1.817 & -3.878 & -4.953 & -4.359 & -3.292 \\
\hline & & $(0.000)$ & $(0.000)$ & $(0.000)$ & $(0.000)$ & $(0.000)$ & $(0.000)$ \\
\hline \multirow[t]{2}{*}{ AREST*Log(TA) } & & & & & & 0.856 & 0.713 \\
\hline & & & & & & $(0.000)$ & $(0.000)$ \\
\hline \multirow[t]{2}{*}{ BFR } & & 0.195 & -2.591 & -3.610 & -3.924 & -2.089 & -1.087 \\
\hline & & $(0.547)$ & $(0.000)$ & $(0.000)$ & $(0.000)$ & $(0.000)$ & $(0.007)$ \\
\hline \multirow[t]{2}{*}{ BFR*Log(TA) } & & & & & & 0.461 & 0.335 \\
\hline & & & & & & $(0.000)$ & $(0.000)$ \\
\hline \multirow[t]{2}{*}{ ST } & & 0.035 & 0.040 & 0.034 & 0.028 & 0.016 & 0.014 \\
\hline & & $(0.000)$ & $(0.000)$ & $(0.000)$ & $(0.000)$ & $(0.000)$ & $(0.000)$ \\
\hline \multirow[t]{2}{*}{ ST*Log(TA) } & & & & & & 0.001 & 0.002 \\
\hline & & & & & & $(0.002)$ & $(0.000)$ \\
\hline \multirow[t]{2}{*}{ DCFPS } & & -2.032 & -2.366 & -2.546 & -1.865 & -5.016 & -5.849 \\
\hline & & $(0.000)$ & $(0.000)$ & $(0.000)$ & $(0.000)$ & $(0.000)$ & $(0.000)$ \\
\hline DCFPS* $\log (\mathrm{TA})$ & & & & & & 1.017 & 1.159 \\
\hline & & & & & & $(0.000)$ & $(0.000)$ \\
\hline GDPG & & $\begin{array}{l}-0.011 \\
\end{array}$ & $\begin{array}{l}-0.087 \\
\end{array}$ & $\begin{array}{l}-0.147 \\
\end{array}$ & -0.111 & -0.182 & -0.099 \\
\hline & & $(0.140)$ & $(0.000)$ & $(0.000)$ & $(0.000)$ & $(0.000)$ & $(0.000)$ \\
\hline GDPG*Log(TA) & & & & & & 0.039 & 0.012 \\
\hline & & & & & & $(0.000)$ & $(0.023)$ \\
\hline GDPPC & & 0.297 & 0.193 & 0.250 & 0.392 & 0.532 & 0.614 \\
\hline & & $(0.000)$ & $(0.000)$ & $(0.000)$ & $(0.000)$ & $(0.000)$ & $(0.000)$ \\
\hline GDPPC* $\log (\mathrm{TA})$ & & & & & & -0.043 & -0.063 \\
\hline & & & & & & $(0.000)$ & $(0.000)$ \\
\hline UR & & 0.129 & 0.077 & 0.037 & 0.014 & 0.055 & 0.086 \\
\hline & & $(0.000)$ & $(0.000)$ & $(0.009)$ & $(0.256)$ & $(0.000)$ & $(0.000)$ \\
\hline UR*Log(TA) & & & & & & -0.036 & -0.044 \\
\hline & & & & & & $(0.000)$ & $(0.000)$ \\
\hline INF & & 0.204 & 0.160 & 0.114 & 0.037 & 0.030 & -0.015 \\
\hline & & $(0.000)$ & $(0.000)$ & $(0.000)$ & $(0.000)$ & $(0.116)$ & $(0.423)$ \\
\hline INF*Log(TA) & & & & & & 0.003 & 0.015 \\
\hline & & & & & & $(0.566)$ & $(0.015)$ \\
\hline NSTIRV & & 0.125 & 0.122 & 0.084 & 0.181 & -0.082 & -0.030 \\
\hline & & $(0.000)$ & $(0.000)$ & $(0.000)$ & $(0.000)$ & $(0.001)$ & $(0.216)$ \\
\hline NSTIRV*Log(TA) & & & & & & 0.056 & 0.033 \\
\hline & & & & & & $(0.000)$ & $(0.000)$ \\
\hline
\end{tabular}




\section{Al Macrothink}

International Finance and Banking

ISSN 2374-2089

2018, Vol. 5, No. 1

\begin{tabular}{|c|c|c|c|c|c|c|}
\hline \multirow[t]{2}{*}{ ISTIRV } & -1.473 & -3.370 & -1.017 & -1.003 & -1.009 & -1.843 \\
\hline & $(0.000)$ & $(0.000)$ & $(0.013)$ & $(0.005)$ & $(0.004)$ & $(0.000)$ \\
\hline \multirow[t]{2}{*}{ ISTIRV*Log(TA) } & & & & & -0.075 & -0.060 \\
\hline & & & & & $(0.000)$ & $(0.012)$ \\
\hline \multirow{2}{*}{ NSTIR-ISTIR } & 0.036 & 0.057 & 0.059 & 0.060 & 0.179 & 0.092 \\
\hline & $(0.001)$ & $(0.000)$ & $(0.000)$ & $(0.000)$ & $(0.000)$ & $(0.000)$ \\
\hline \multirow[t]{2}{*}{ (NSTIR-ISTIR)*Log(TA) } & & & & & -0.038 & -0.030 \\
\hline & & & & & $(0.000)$ & $(0.000)$ \\
\hline \multirow[t]{2}{*}{ BTC/GDP } & & 3.901 & 4.564 & 1.467 & 2.921 & -15.254 \\
\hline & & $(0.000)$ & $(0.000)$ & $(0.011)$ & $(0.000)$ & $(0.000)$ \\
\hline \multirow[t]{2}{*}{ BTC/GDP*Log(TA) } & & & & & & 5.865 \\
\hline & & & & & & $(0.000)$ \\
\hline \multirow[t]{2}{*}{$(1+\mathrm{M} 2 \mathrm{G}) /(1+\mathrm{RESG})$} & & 0.003 & 0.001 & 0.001 & 0.003 & 0.000 \\
\hline & & $(0.290)$ & $(0.779)$ & $(0.655)$ & $(0.262)$ & $(0.962)$ \\
\hline \multirow[t]{2}{*}{$(1+\mathrm{M} 2 \mathrm{G}) /(1+\mathrm{RESG}) * \log (\mathrm{TA})$} & & & & & & 0.003 \\
\hline & & & & & & $(0.085)$ \\
\hline \multirow[t]{2}{*}{ REER } & & 0.000 & -0.000 & 0.000 & 0.000 & 0.000 \\
\hline & & $(0.480)$ & $(0.145)$ & $(0.458)$ & $(0.897)$ & $(0.001)$ \\
\hline \multirow[t]{2}{*}{ REER*Log(TA) } & & & & & & -0.000 \\
\hline & & & & & & $(0.000)$ \\
\hline \multirow[t]{2}{*}{ VOLDEMMN } & & -0.211 & -0.419 & -0.313 & -0.284 & -0.478 \\
\hline & & $(0.000)$ & $(0.000)$ & $(0.000)$ & $(0.000)$ & $(0.000)$ \\
\hline \multirow[t]{2}{*}{ VOLDEMMN*Log(TA) } & & & & & & 0.069 \\
\hline & & & & & & $(0.000)$ \\
\hline \multirow{2}{*}{ REER*NORD } & & & -0.000 & -0.000 & -0.000 & -0.000 \\
\hline & & & $(0.712)$ & $(0.000)$ & $(0.000)$ & $(0.000)$ \\
\hline \multirow[t]{2}{*}{ REER*PTSPIT } & & & 0.000 & 0.000 & -0.000 & -0.000 \\
\hline & & & $(0.040)$ & $(0.028)$ & $(0.127)$ & $(0.002)$ \\
\hline \multirow[t]{2}{*}{ CRIS } & & & -0.500 & 1.827 & 0.019 & 0.500 \\
\hline & & & $(0.050)$ & $(0.000)$ & $(0.935)$ & $(0.470)$ \\
\hline \multirow[t]{2}{*}{ CRIS*Log(TA) } & & & & & & -0.466 \\
\hline & & & & & & $(0.053)$ \\
\hline \multirow[t]{2}{*}{ VOLDEMMN*CRIS } & & & 0.266 & 0.195 & 0.179 & 0.302 \\
\hline & & & $(0.000)$ & $(0.000)$ & $(0.000)$ & $(0.000)$ \\
\hline \multirow[t]{2}{*}{ VOLDEMMN*CRIS*Log(TA) } & & & & & & -0.050 \\
\hline & & & & & & $(0.001)$ \\
\hline \multirow[t]{2}{*}{ REER*CRIS } & & & 0.000 & -0.000 & -0.000 & -0.000 \\
\hline & & & $(0.065)$ & $(0.000)$ & $(0.350)$ & $(0.472)$ \\
\hline \multirow[t]{2}{*}{ REER*CRIS*Log(TA) } & & & & & & 0.000 \\
\hline & & & & & & $(0.117)$ \\
\hline
\end{tabular}

Note. The values in parentheses are p-values.

\subsection{Bank-Specific Variables}

The first important conclusion that can be drawn from our results is that the relationship between bank-specific variables and the net interest margin is not linear.

Our results are robust: the direction of influence for each explanatory variable is generally stable as we progress from regression 1 to regression 7 . One notable exception is the coefficient for $\log$ (TA) in the commercial bank sample: when we allow the impact of regulatory and macro variables to depend on bank size (regression 6), the coefficient of $\log$ (TA) switches from negative to positive. This means that bigger commercial banks tend to have higher margins. Among savings, investment, real estate and cooperative banks, however, 
this coefficient is negative in all regressions. A negative sign for this coefficient has previously been interpreted as consistent with the existence of scale economies (Demirguç-Kunt et al., 2004).

A second exception is the MS variable, again for commercial banks. We find a positive relationship between MS and NIM in regressions 1 to 5, but allowing the impact of regulatory and macro variables to depend on bank size changes things. The estimated marginal impact of MS on NIM (Note 14) has a minimum at MS $=50.5 \%$. Note, however, that the commercial sample's maximum MS value is $44.6 \%$. This means that the impact of MS on NIM is always negative in practice. One possible explanation is product differentiation: if bank products and services are differentiated and market demand is small relative to bank size, then higher NIM is associated with lower market shares. (Note 15) The relationship between MS and NIM is positive in the non-commercial sample.

Banks with higher product diversification $(\mathrm{OFF} 2=1$ and $\mathrm{OFF} 3=1)$ exhibit lower interest margins regardless of specialization. (Note 16) This is consistent with the cross-subsidization of bank activities. (Note 17) Changing the definition of the groups does not significantly change our results (results not shown).

Less leveraged commercial banks (i.e., those with higher ETA) have higher NIM, which is consistent with theories stressing that better capitalized banks can charge more for loans and/or pay less on deposits because they face lower bankruptcy risks. However, among non-commercial banks "middle" leveraged $($ ETA2 $=1)$ non-commercial banks exhibit lower margins than higher leveraged ones.

The estimated relationships between continuous bank-specific variables and NIM, using regression 7, are given in Table 7. Since the model assumes quadratic dependence, the relationships are drawn as U-shaped curves. Table 7 shows the shape of the relationship, the value of the bank-specific variable for which the impact is maximized or minimized, and the number of observations whose bank-specific variable lies above or below the minimum/maximum. For example, NIM is an inverted U-shaped function of CTI for both commercial and non-commercial banks. Among commercial banks, the value that maximizes NIM is CTI $=0$. There are only 13 observations in our sample with CTI $<0$, and 5739 with CTI $>0$. Thus, the relevant shape is the downward-sloping segment of the inverted U.

Banks are similar with respect to the impact of the earning assets ratio on NIM for relevant magnitudes: increasing TEATA has a negative impact on bank interest margins. The fact that higher risk is "rewarded" with higher margins means that all banks are able to charge higher ex-ante interest rates, which translate into higher ex-post interest received.

Banks also display a uniform response to the LTA ratio, being able to transform funding into profitable applications. There is a critical level of lending (estimated at $74 \%(52 \%)$ of the total assets for commercial (non-commercial) banks) beyond which NIM decreases.

For relevant magnitudes of the cost-to-income ratio we find that, among commercial banks, higher inefficiency is associated with lower margins, meaning that they are not able to pass their inefficiencies on to customers. Non-commercial banks exhibit a slightly different 
behaviour: those with a CTI ratio below $61 \%$ (29.6\% of the sample) are able to pass their inefficiency on to customers, but those with higher CTI ratios cannot.

Table 7. Estimated relationships between bank-specific variables and NIM (regression 7)

\begin{tabular}{|c|c|c|c|c|c|c|}
\hline & \multicolumn{3}{|c|}{ Commercial Banks } & \multicolumn{3}{|c|}{ Non-commercial Banks } \\
\hline & $\begin{array}{l}\text { Relevant } \\
\text { Shape }\end{array}$ & Min/Max & $\begin{array}{l}\# \quad \text { obs } \\
\text { below/above } \\
\text { Min (Max) }\end{array}$ & $\begin{array}{l}\text { Relevant } \\
\text { Shape }\end{array}$ & Min/Max & $\begin{array}{l}\# \text { obs } \\
\text { below/above } \\
\text { Min (Max) }\end{array}$ \\
\hline CTI & & 0 & $13 / 5,739$ & & 61.4 & $\begin{array}{l}4,249 \\
10,088\end{array}$ \\
\hline LTA & & 74.1 & $5,031 / 721$ & & 52.2 & $4,541 / 9,841$ \\
\hline LLPGL & & -19.5 & $11 / 5,741$ & & 21.3 & $14,374 / 8$ \\
\hline TEATA & & 77.6 & $120 / 5,632$ & & 99.2 & $14,142 / 240$ \\
\hline MS & & 50.5 & $5,752 / 0$ & & 11.3 & $14,353 / 29$ \\
\hline
\end{tabular}

\subsection{Macroeconomic and Regulatory Variables}

Macroeconomic and regulatory variables also affect bank interest margins, but the magnitude and sign of their impact depends more on bank specialization and size. Using regression 7 , the estimated impact of a one-unit change in macroeconomic and regulatory variables on the net interest margin is given in Tables 8 and 9 .

Table 8 shows the impact of a one-unit change in CR5 on NIM, as a function of Total Assets. Among commercial banks the CR5 coefficient is positive and significant, but the coefficient of the cross-product CR5* $\log (\mathrm{TA})$ is not significant (at the $5 \%$ significance level). This means that the impact of a one-unit change in CR5 on NIM is always positive and independent of bank size. This result is consistent with the findings of Molyneux et al. (1994) and Neven \& Roller (1999). Results for the non-commercial bank sample are very different: the coefficient of the cross-product $\mathrm{CR} 5^{*} \log (\mathrm{TA})$ is now positive and significant, so the impact of CR5 on NIM does depend on bank size. For bank sizes up to 14 billion euros $(77 \%$ of the sample) the impact of CR5 is negative, and it becomes positive for larger banks (23\% of the sample). 


\section{$\triangle$ Macrothink}

Table 8. Estimated impact of a one-unit CR5 change on NIM (regression 7), as a function of bank size (TA)

dNIM/dCR5

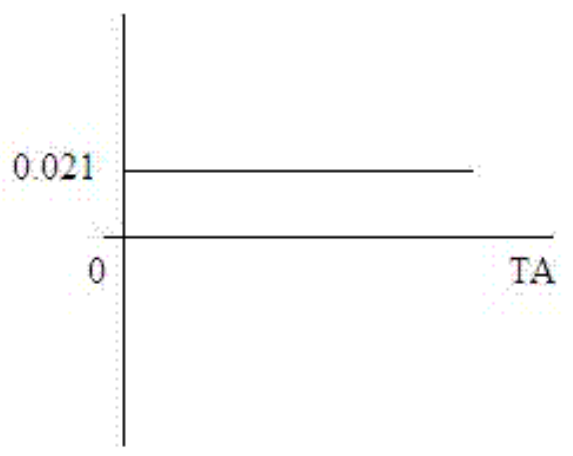

Commercial banks
dNIM/dCR 5

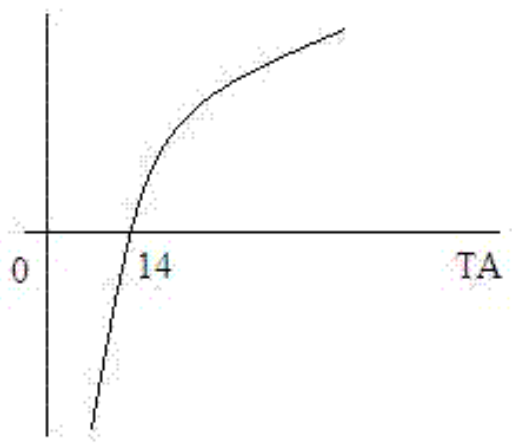

Non-commercial banks

Similar graphs for the remaining macro and regulatory variables are sketched in Table 9. Strong activity restrictions are associated with lower NIM for commercial banks as well as small to medium-sized non-commercial banks. This result contradicts the findings of Demirguç-Kunt et al. (2004). One should note, however, that in regression 2 (for both samples) AREST has a significantly positive sign in qualitative agreement with that research. This sign reverses only when we include the policy and crisis variables.

The effect of banking freedom on NIM is usually negative: more freedom leads to lower margins. The difference between commercial and non-commercial banks is interesting, however. While the former exhibit continuously decreasing margins, among non-commercial organizations the impact of BRF on NIM approaches zero then becomes positive as the bank size increases. The estimated impact of BRF on NIM is positive for only $13 \%$ of the sample: the largest non-commercial banks.

The estimated impact of stock market development on NIM is positive, suggesting that equity and debt financing are complements. We find that $\mathrm{dNIM} / \mathrm{dST}$ is positive (but decreasing with bank size) for commercial banks, and positive (but increasing with bank size) for non-commercial banks. The level of development of the stock market may improve NIM because stock markets generate information about firms that is useful to banks, among other reasons. A highly developed market also requires a sound legal and regulatory environment, which also improves the functioning of banks.

The level of institutional development is important but influences the two types of banks differently: non-commercial banks are positively influenced by GDPPC, and commercial banks are not.

Portuguese and Spanish banks suffered from the full liberalization of capital movements. (Note 18) Given the increased competition brought about by liberalization, their banks were forced to reduce NIM regardless of size or type. Moreover, as fund holders looked abroad for 


\section{Macrothink}

more efficient banking systems and more profitable applications, capital flowed out of the country. The damage caused by financial liberalization (in terms of decreased interest rate margins and returns) was stronger than the benefits eventually brought by capital freedom for all types of banks.

Table 9. Estimated impact of a one-unit change in various macroeconomic and regulatory variables on NIM (regression 7), as a function of bank size (TA)

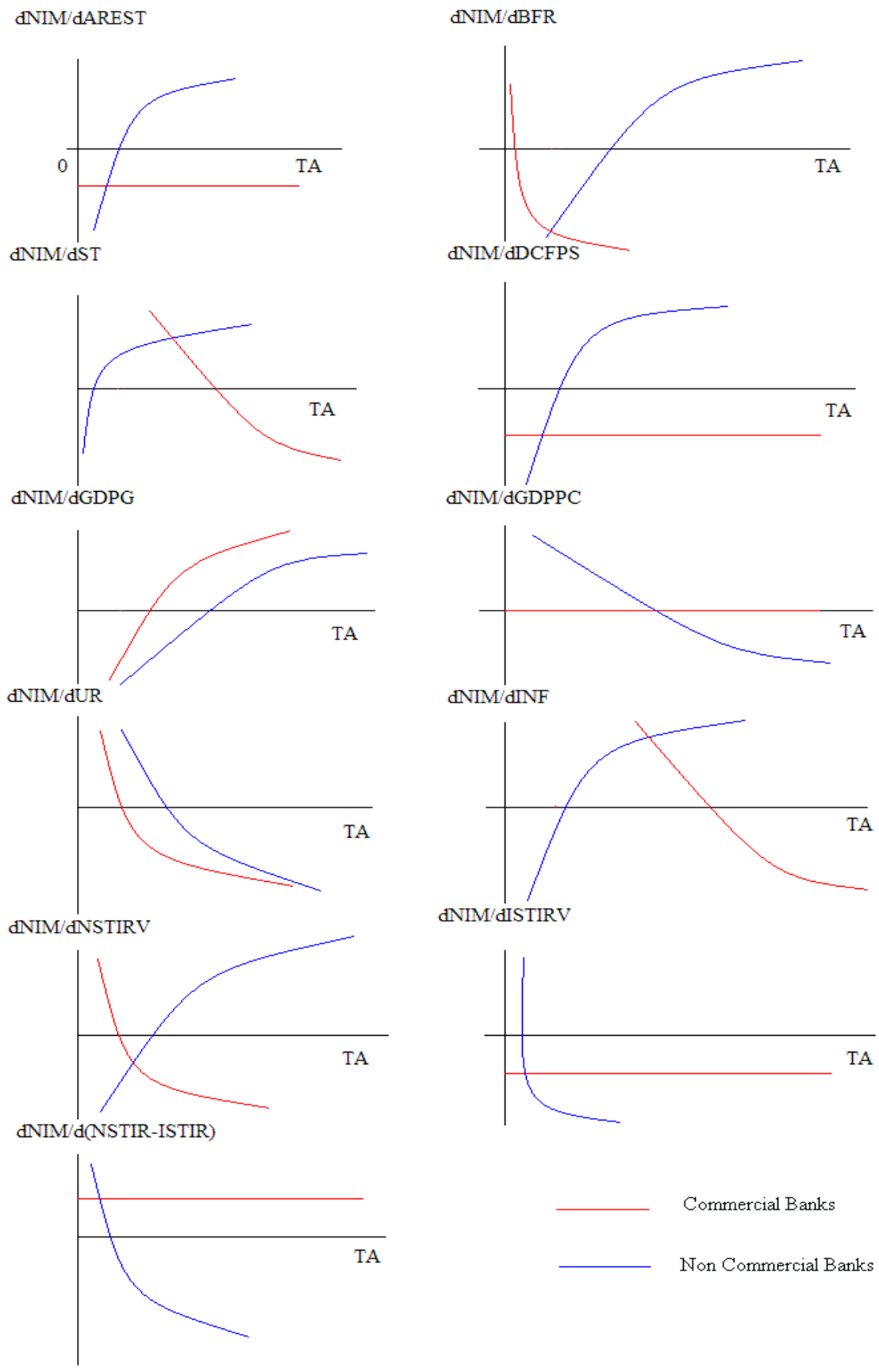


The business cycle does impact net interest margins. We conclude from our results that declining aggregate growth rates may weaken the debt servicing capacity of domestic borrowers and increase the credit risk. This increase in risk is compensated for by higher spreads. Thus, given that interest margins vary endogenously in response to aggregate productivity shocks, the change in NIM becomes an additional channel through which productivity shocks affect economic activity. (Note 19)

The impact of the unemployment rate is similar in commercial and non-commercial banks: positive (but declining with size) for smaller banks, and negative for medium-sized and larger institutions. As for inflation, its impact depends on both bank specialization and size. The NIM of commercial banks worsens with inflation, but among larger non-commercial banks NIM improves under the same conditions. The negative relationship found in commercial banks and smaller non-commercial banks is in agreement with earlier research (Petersen, 1986), but contradicts more recent studies (Claessens et al., 2001; Demirguç-Kunt \& Huizinga, 1999; 2000; Demirguç-Kunt et al., 2004).

The difference between domestic and international interest rates (NSTIR-ISTIR) has a positive impact on NIM for the vast majority of observations. In fact, dNIM/d(NSTIR-ISTIR) is found to be negative only among the largest $15 \%$ of non-commercial banks.

Evidence for the effect of domestic interest rate risk (NSTIRV) on NIM is mixed. There is some instability in the commercial bank sample estimates, although the coefficient seems to stabilize in regressions 6 and 7. According to regression 7 estimates, dNIM/dNSTIRV is positive (and declining with bank size) for the smallest $36 \%$ of commercial banks and negative for the remainder. In the non-commercial bank sample, estimates of this coefficient are more stable. When we allow bank size to interact with regulatory, macro, policy and crisis variables (i.e., regressions 6 and 7), we find that dNIM/dNSTIRV is negative (but increasing with size) for the smallest non-commercial banks (14\% of the sample) and positive for all others. The effect of international interest rate risk appears to be similar for all banks: higher volatility decreases NIM.

\subsection{Policy and Macro-Financial Variables}

In Table 10 (like Table 9) we show the estimated impact of a one-unit change in the policy and macro-financial variables. All banks are sensitive to their country's vulnerability to a balance of payments crisis, or rather to the implied risk of liquidity problems brought about by such a crisis. How banks feel about this risk, however, depends on their specialization. Commercial banks are concerned that current accounts and the level of foreign reserves may become unsustainable, while non-commercial banks are only worried about the current accounts. (Note 20)

The Real Effective Exchange Rate does not seem to have an impact on NIM for commercial banks (at least at the 5\% significance level) (Note 21), but it does have a significant positive (declining with bank size) impact on non-commercial banks. Nevertheless, during the period of exchange rate turmoil (CRIS=1) commercial banks were able to increase NIM (the coefficient of REER* CRIS is positive and significant). One could argue that commercial 


\section{Macrothink}

banks were able to justify their lending rate increases during crisis years by citing the concomitant exchange rate instability.

Table 10. Estimated impact of a one-unit change in policy and macro-financial variables on NIM (regression 7), as a function of bank size (TA)

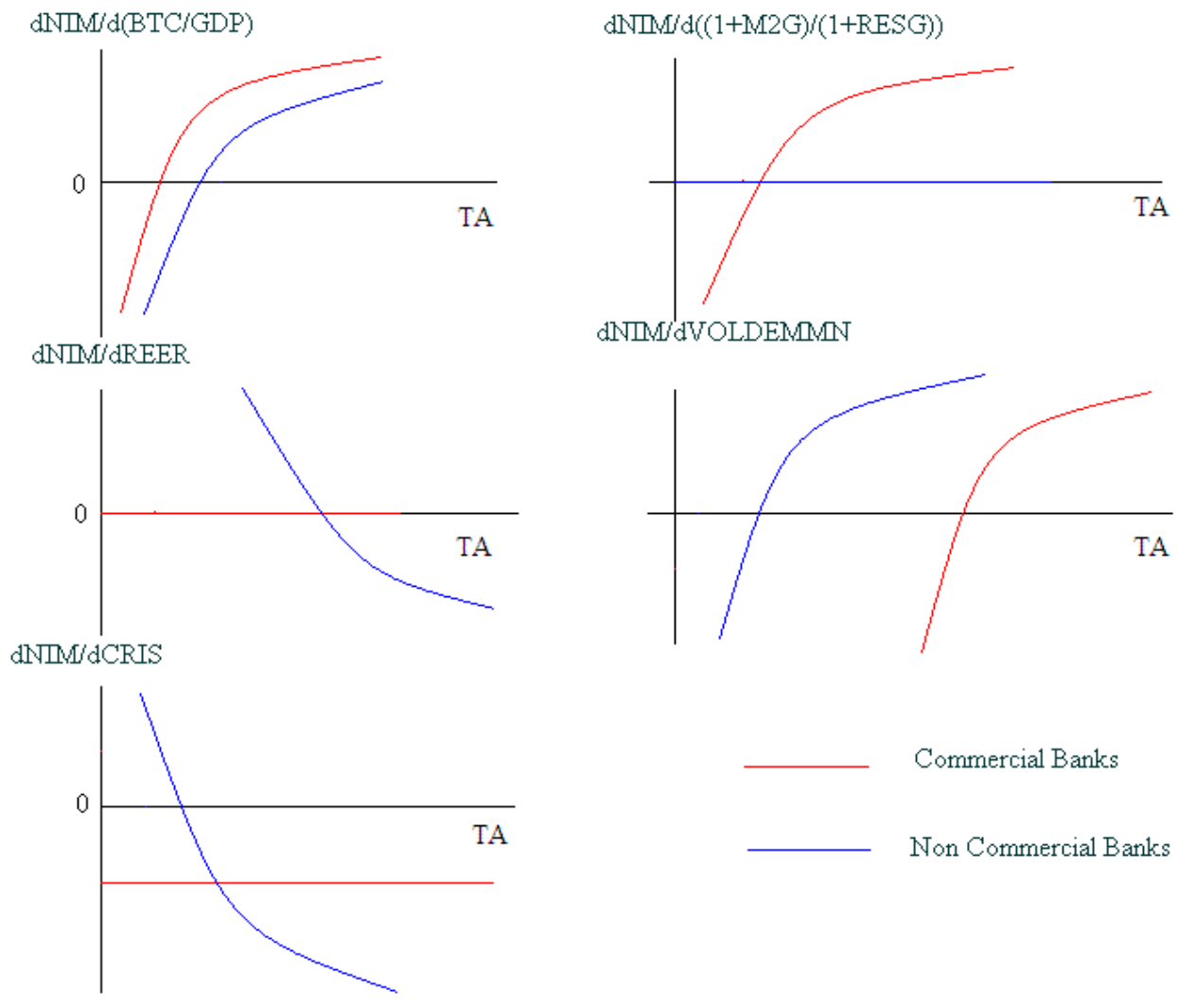

The volatility of the exchange rate does have a clear negative impact on commercial banks and smaller non-commercial banks. It also has a positive impact on medium-sized and larger non-commercial institutions. The impact of VOLDEMMN on NIM for commercial banks is the same throughout the entire sample period (including EMS crisis years). Non-commercial banks were able to adjust during EMS crisis years, however, the impact of exchange rate volatility becoming positive for most such organizations.

The EMS crisis of 1992/3/4 had a negative impact on interest margins. Under pressure, European domestic monetary authorities reacted by increasing short-term interest rates. This policy also had an impact on medium- and long-term rates, which contributed to lower margins.

\subsection{Additional Sensitivity Tests}

\subsubsection{Outliers}

As mentioned in section 3.1, some individual banks exhibit aberrant data and were excluded 
from the sample. Still, it could be argued that non-aberrant outliers also have the potential to bias our results. We therefore re-estimated our model (column 7 in the previous tables) for a slightly smaller sample, in which those observations with the highest and lowest NIM values were excluded. (Note 22)

Furthermore, the CTI ratio as defined here (see Appendix) can sometimes exhibit negative and very high positive values. To account for this oddity, we restricted the sample to data with positive CTI values below $200 \%$. Another potential problem is that some banks have a negative LLPGL ratio. Thus, all observations with $L L P G L<0$ were excluded from the sample and the model re-estimated. Results for the "cleaned" sub-samples were essentially unchanged (not reported).

\subsubsection{Effect of Bank Liquidity on NIM}

It could be argued that bank liquidity is a relevant and omitted variable. Banks with more liquid assets or a higher asset-liability liquidity mismatch could indeed display different NIMs. Amongst the bank-specific variables, we also tested the effects of the liquid assets to customer and short-term funding ratio. Unfortunately, the available data on liquid assets are insufficient to compute the ratio; too many observations are lost, especially for Portugal and Italy. Results (not reported) obtained while including this variable are not significantly different.

\subsubsection{Germany}

A final concern (particularly for non-commercial banks) is that the sample is heavily biased towards Germany, which provides $67.4 \%$ of the non-commercial bank-year observations (Table 1). To address this concern, we excluded Germany from both samples and re-estimated the model. Results for the commercial bank sample are similar (not reported). As for the non-commercial bank sample, we do obtain slightly different results for the BFR, INF and CRIS variables: INF and CRIS become non-significant. As for BFR, its coefficient is statistically zero. The cross-product BFR* $\log (\mathrm{TA})$ still has a positive coefficient, meaning that yet more observations exhibit a positive influence of BFR on NIM. All other conclusions remain unchanged.

\section{Final Remarks}

We find that bank's NIM is sensitive to the country's vulnerability to balance of payment and currency crises. How a bank feels about the added liquidity risk brought about by this vulnerability, however, depends on its specialization. Commercial banks are concerned with the current account and the level of foreign reserves, both of which may be unsustainable, while non-commercial banks are only worried about the current account. We may speculate that commercial banks are more vulnerable to the possibility of sudden capital outflows in countries with an exchange rate peg.

The volatility of the exchange rate has a negative impact on commercial banks and smaller non-commercial banks, but a positive impact on medium-sized and larger non-commercial institutions. The EMS crisis of the early nineties had a negative impact on NIM for the 
majority of banks. Thus, both bank specialization and size should be accounted for in future studies of bank performance.

Bank regulations, market structure, macroeconomic variables, and financial sector conditions strongly influence bank margins. Indicators of economic development, both nominal and real, also have an effect on bank performance.

Our results allow us to draw some conclusions that are relevant to today's banking: they shed light on some of the concerns created by the financial events linked to the US sub-prime mortgage crisis. The instability of international financial markets is not good for banks, as higher interest and exchange rate volatilities generally have a negative impact on NIM.

As for the regulatory environment, we anticipate that in the new EU member countries the opening up and further development of the banking industry will create multiple contradictory effects, whose global outcome remains unclear. Opening the banking industry to new markets and giving banks more freedom to operate their businesses will increase competition and lower NIM, but the weakening (or complete removal) of restrictions on financial activity will allow many banks to directly benefit from diversification. Banks can improve performance by allocating resources outside their existing lines of business. Moreover, the development of the stock market will improve margins. Not only do stock markets generate information about firms that is useful to banks, but a smoothly functioning stock market requires a sound legal and regulatory environment. Any strengthening of prudential, supervisory and accounting standards will also improve the functioning of banks and bank performance.

Our results have policy implications. Given that interest margins vary endogenously in response to aggregate productivity shocks, the change in NIM becomes an additional channel through which productivity shocks affect economic activity. As interest margins are countercyclical, credit becomes more expensive in bad times; hence, firms may postpone their investments and the decline in economic activity may be made even worse, calling for stabilization policies.

Finally, there is evidence that banks are vulnerable to market interest rate risk. Both banks and supervisors should therefore pay close attention to market developments that could lead to excessive risk-taking activity. This point is of particular concern to regulatory and supervisory authorities.

\section{Acknowledgements}

UECE is supported by the Fundacão para a Ciência e a Tecnologia (Portuguese Foundation for Science and Technology). This article is part of the Strategic Project (UID/ECO/00436/2013).

The opinions expressed in this document are those of the author, and not necessarily those of the CMVM. CEFAGE-UE is supported by the Fundação para a Ciência e a Tecnologia - Portuguese Foundation for Science and Technology (grant UID/ECO/04007/2013) and FEDER/COMPETE (POCI-01-0145-FEDER-007659). 


\section{References}

Allen, L. (1988). The Determinants of Bank Interest Margins: A Note. Journal of Financial and Quantitative Analysis, 23, 231-235. https://doi.org/10.2307/2330883

Angbazo, L. (1997). Commercial Bank Net Interest Margins, Default Risk, Interest-rate Risk, and Off-balance Sheet Banking. Journal of Banking and Finance, 21(1), 89-112. https://doi.org/10.1016/S0378-4266(96)00025-8

Angelini, P., \& Cetorelli, N. (2003). The Effects of Regulatory Reform on Competition in the Banking Industry. Journal of Money, Credit and Banking, 35(5), 663-684.

Barth, J., Caprio, G., \& Levine, R. (2001). The Regulation and Supervision of Banks Around the World: A New Database. Policy Research Working Paper 2588. World Bank, Washington, DC. Retrieved from https://openknowledge.worldbank.org/handle/10986/19664 License: CC BY 3.0 IGO.

Barth, J., Nolle, D., Phumiwasana, T., \& Yago, G. (2003). A Cross-Country Analysis of the Bank Supervisory Framework and Bank Performance. Financial Markets, Institutions \& Instruments, 12(2), 67-120.

Berger, A., Demirguç-Kunt, A., Levine, R., \& Haubrich, J. (2004). Bank Concentration and Competition: An Evolution in the Making. Journal of Money, Credit and Banking, 36(3), 433-452. https://doi.org/10.1353/mcb.2004.0040

Berger, A., Rosen, R., \& Udell, G. (2007). Does Market Size Structure Affect Competition? The Case of Small Business Lending. Journal of Banking and Finance, 31(1), 11-33.

Bernanke, B., \& Gertler, M. (1989). Agency Costs, Net Worth, and Business Fluctuations. American Economic Review, 79(1), 14-31.

Calvo, G. (1996). Capital Flows and Macroeconomic Management: Tequila Lessons. International Journal of Finance \& Economics, (1), 207-224. https://doi.org/10.1002/(SICI)1099-1158(199607)1:3<207::AID-IJFE21>3.0.CO;2-3

Carbó-Valverde, S., \& Fernández, F. (2007). The Determinants of Bank Margins in European Banking. Journal of Banking and Finance, 31(7), 2043-2063. https://doi.org/10.1016/j.jbankfin.2006.06.017

Claessens, S., Demirguc-Kunt, A., \& Huizinga, H. (2001). How Does Foreign Entry Affect Domestic Banking Markets?. Journal of Banking and Finance, 25(5), 891-911. https://doi.org/10.1016/S0378-4266(00)00102-3

Demirguç-Kunt, A., \& Detragiache, E. (1997). The Determinants of Banking Crises Evidence from Industrial and Developing Countries. World Bank Development Research Group and International Monetary Fund Research Department, Policy Research WP 1828.

Demirguç-Kunt, A., \& Huizinga, H. (1999). Determinants of Commercial Bank Interest Margins and Profitability: Some International Evidence. The World Bank Economic Review, 13(2), 379-408. https://doi.org/10.1093/wber/13.2.379 


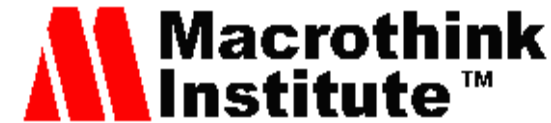

Demirguç-Kunt, A., \& Huizinga, H. (2000). Financial Structure and Bank Profitability. World Bank Policy Research WP 2430.

Demirguç-Kunt, A., \& Maksimovic, V. (1996). Stock Market Development and Firm Financing Choices. World Bank Economic Review, 10(2), 341-369.

Demirguç-Kunt, A., Laeven, L., \& Levine, R. (2004). Regulations, Market Structure, Institutions, and the Cost of Financial Intermediation. Journal of Money, Credit and Banking, 36(3), 593-622. https://doi.org/10.3386/w9890

DeYoung, R., Hunter, W., \& Udell, G. (2004). The Past, Present, and Probable Future for Community Banks. Journal of Financial Services Research, 25(2/3), 85-133. https://doi.org/10.1023/B:FINA.0000020656.65653.79

Entrop, O., Memmel, C., Ruprecht, B., \& Wilkens, M. (2015). Determinants of Bank Interest Margins: Impact of Maturity Transformation. Journal of Banking and Finance, 54, 1-19. https://doi.org/10.1016/j.jbankfin.2014.12.001

Evans, O., Leone, A., Gill, M., \& Hilbers, P. (2000). Macroprudential Indicators of Financial System Soundness. International Monetary Fund, Washington DC, Occasional paper 192.

Hanweck, G., \& Ryu, L. (2005). The Sensitivity of Bank Net Interest Margins and Profitability to Credit, Interest-Rate, and Term-Structure Shocks Across Bank Product Specializations. FDIC Working Paper 2005-02. http://dx.doi.org/10.2139/ssrn.886727

Ho, T., \& Saunders, A. (1981). The Determinants of Bank Interest Margins: Theory and Empirical Evidence. Journal of Financial and Quantitative Analysis, 16, 581-600. https://doi.org/10.2307/2330377

Islam, M., \& Nishiyama, S. (2016). The Determinants of Bank Net Interest Margins: A Panel Evidence from South Asian Countries. Research in International Business and Finance, 37, 501-514.

Kaminsky, G. (2003). Varieties of Currency Crises. National Bureau of Economic Research WP 10193.

Laeven, L., \& Majnoni, G. (2005). Does Judicial Efficiency Lower the Cost of Credit?. Journal of Banking and Finance, 29(7), 1791-1812. https://doi.org/10.1016/j.jbankfin.2004.06.036

Levine, R. (2004). Denying Foreign Bank Entry: Implications for Bank Interest Margins. In L. A. Ahumada \& J. R. Fuentes, S. Chile (Eds.), Bank Market Structure and Monetary Policy (pp. 271-292). Banco Central de Chile.

Lin, J., Chung, H., Hsieh, M., \& Wu, S. (2012). The Determinants of Interest Margins and Their Effect on Bank Diversification: Evidence from Asian Banks. Journal of Financial Stability, 8(2), 96-106. https://doi.org/10.1016/j.jfs.2011.08.001

Lloyd-Williams, D., \& Thornton, J. (1994). Competitive Conditions in European Banking. Journal of Banking and Finance, 18, 445-459. https://doi.org/10.1016/0378-4266(94)90003-5 
Maudos, J., \& Guevara, J. (2004). Factors Explaining the Interest Margin in the Banking Sectors of the European Union. Journal of Banking and Finance, 28, 2259-2281. https://doi.org/10.1016/j.jbankfin.2003.09.004

Mishkin, F. (2001). Financial Policies and the Prevention of Financial Crises in Emerging Market Countries. National Bureau of Economic Research WP 8087.

Neven, D., \& Roller, L. (1999). An Aggregate Structural Model of Competition in the European Banking Industry. International Journal of Industrial Organization, 17(7), 1059-1074. https://doi.org/10.1016/S0167-7187(97)00068-4

Petersen, W. (1986). The Effects of Inflation on Bank Profitability. Recent Trends in Commercial Bank Profitability-A Staff Study (pp. 89-114). Federal Reserve Bank of New York.

Samuel, W., \& Valderrama, L. (2006). The Monetary Policy Regime and Banking Spreads in Barbados. IMF Working Paper WP/06/211. http://dx.doi.org/10.5089/9781451864717.001

Santos, J., \& Winton, A. (2008). Bank Loans, Bonds, and Information Monopolies across the Business Cycle. Journal of Finance, 63(3), 1315-1359. https://doi.org/10.1111/j.1540-6261.2008.01359.x

Saunders, A., \& Schumacher, L. (2000). The Determinants of Bank Interest Rate Margins: An International Study. Journal of International Money and Finance, 19, 813-832. https://doi.org/10.1016/S0261-5606(00)00033-4

Swamy, P., Barth, J., Chou, R., \& Jahera Jr., J. (1996). Determinants of US Commercial Bank Performance: Regulatory and Econometric Issues. Research in Finance, 14, 117-156.

Williamson, J. (2000). Exchange Rate Regimes for Emerging Markets: Reviving the Intermediate Option. Institute for International Economics, Washington, DC.

Wong, K. (1997). On the Determinants of Bank Interest Margins Under Credit and Interest Rate Risks. Journal of Banking and Finance, 21(2), 251-271. https://doi.org/10.1016/S0378-4266(96)00037-4

World Bank. (2003). World Bank Development Indicators. [Online] Available: http://documents.worldbank.org/curated/en/973231468331252903/World-development-indica tors-2003

\section{Notes}

Note 1. We do not go beyond 1998 because we want to test the effect of the exchange rate policy; the creation of the Euro in Europe in 1999 would not allow us to study the impact of exchange rate policy if one was to use information from 1999 and beyond. Data are provided for commercial, savings, investment, real estate and cooperative banks. For financial reporting, we use unconsolidated statements. Even though Ireland was a full member of the EMS during this period, it is not included in the study due to a lack of bank-specific data. 
Note 2. "One advantage of using data averaged over the 1995-99 period is that we smooth variables that vary over time" (Demirguç-Kunt et al., 2004, p. 598).

Note $3 . \quad$ [Online] Available:

http://europa.eu.int/comm/economy_finance/publications/europeaneconomy_en.htm.

Note 4. Data is not adjusted for any mergers and acquisitions that occurred over the sample period.

Note 5. Assets are measured in 1994 prices. Alternatively, we tried using the following variables to capture bank size relative to the total assets of the country's largest bank: SIZE1 $=1$ if a bank's total assets are less than $0.5 \%$ of this maximum; SIZE2 $=1$ if a bank's total assets are greater than $0.5 \%$ but less than $25 \%$ of the maximum; and SIZE3 $=1$ if a bank's total assets are greater than $25 \%$ of the maximum. The results (not shown) are consistent with the existence of a U-shaped relationship.

Note 6 . OFF 1 is omitted in our regressions. The $15 \%$ and $40 \%$ limits were chosen in order to create "balanced groups" (see Table 3). The sensitivity of our results to these limits is very limited (results not reported).

Note 7. ETA1 is omitted in our regressions. We performed a sensitivity analysis on these limits, obtaining very similar results (not reported). We also ran regressions using linear and quadratic functions of the off-balance earnings and equity, but in both cases the quadratic terms were not significant. The use of dummy variables is a more flexible approach, allowing us to test for the possibility that different size categories have different impacts.

Note 8 . The definition of a bank's relevant market is therefore important. The clear majority of papers on banking (non-US studies) treat the entire nation as a single market, as we do in this paper.

Note 9. The sample of banks covered by this database increased significantly over the period 1988-98. Annual changes in this measure of the concentration may just reflect changes in sample coverage.

Note 10 . Borrowing rates are characterized by more inertia than lending rates, so any shocks to interest rates should be associated with increased margins.

Note 11. Levine (2004) found that regulatory restrictions on the entry of foreign banks are linked with bank margins, rather than the level of foreign-owned banks. As the entry of foreign banks was permitted in all countries of this sample, we did not control for either of these restrictions.

Note 12. The non-commercial sample includes investment, savings, real estate and cooperative banks. The sample was split in order to check the influence of bank specialization on our results.

Note 13. Demirguç-Kunt \& Huizinga (1999) and Claessens et al. (2001) use a similar methodology.

Note 14 . This is given by $\mathrm{dNIM} / \mathrm{dMS}=-0.041361+2 * 0.000499 * \mathrm{MS}$, from regression 7 . 
Note 15. Berger et al. (2007) found that greater market shares for large US banks are associated with lower interest rates on SME loans, thereby leading to lower interest margins.

Note 16. The (absolute value of the) coefficient of OFF3 is always higher than that of OFF2, suggesting that higher off-balance activity implies lower net interest margins.

Note 17. A similar result is found in Demirguç-Kunt et al. (2004).

Note 18. Samuel \& Valderrama (2006) found similar results.

Note 19. This is consistent with the findings of Santos \& Winton (2008), who conclude that bank loan spreads are higher for bank-dependent firms than for firms with access to public bond markets. The spreads rise for both types of firms during a recession, but they rise more for bank-dependent firms.

Note 20. At the usual 5\% significance level.

Note 21. Nordic countries exhibit lower NIMs. Commercial banks in the 3 associated countries of South Europe (Portugal, Spain and Italy), however, were not noticeably different from other non-Nordic countries. The coefficient of REER interacting with PTSPIT (non-commercial banks) is very unstable.

Note 22. Quantiles 1 and 99 were excluded.

\section{Appendix.}

Variable Definitions

\begin{tabular}{|c|c|c|c|}
\hline NIM & $\begin{array}{ll}\text { Net } & \text { Interest } \\
\text { Margin } & \end{array}$ & $\begin{array}{l}\text { (Interest Income-Interest Expense) / Average Interest } \\
\text { Bearing Assets }(* 100)\end{array}$ & Bankscope \\
\hline TA & $\begin{array}{l}\text { Total Assets, } 1994 \\
\text { prices }\end{array}$ & Total Assets / Consumer Price Index & $\begin{array}{l}\text { Bankscope, European } \\
\text { Commission }\end{array}$ \\
\hline $\begin{array}{l}\text { OFF/TE } \\
\text { A }\end{array}$ & $\begin{array}{l}\text { Off balance } \\
\text { activity }\end{array}$ & Off-Balance Items / Total Earning Assets & Bankscope \\
\hline OFF1 & Dummy variable & Equal to 1 if $\mathrm{OFF} / \mathrm{TEA}<0.05$ & Own calculation \\
\hline OFF2 & Dummy variable & Equal to 1 if $0.05 \leq \mathrm{OFF} / \mathrm{TEA}<0.15$ & Own calculation \\
\hline OFF3 & Dummy variable & Equal to 1 if $\mathrm{OFF} / \mathrm{TEA} \geq 0.15$ & Own calculation \\
\hline ETA & $\begin{array}{l}\text { Equity to Total } \\
\text { Assets ratio }\end{array}$ & Equity / Total Assets & Bankscope \\
\hline ETA1 & Dummy variable & Equal to 1 if ETA $<0.02$ & Own calculation \\
\hline ETA2 & Dummy variable & Equal to 1 if $0.02 \leq \mathrm{ETA}<0.05$ & Own calculation \\
\hline ETA3 & Dummy variable & Equal to 1 if ETA $\geq 0.05$ & Own calculation \\
\hline CTI & $\begin{array}{l}\text { Cost-to-Income } \\
\text { ratio }\end{array}$ & $\begin{array}{l}\text { Operating Costs / (Interest Income-Interest Expense + } \\
\text { Other Operating Income)*100 }\end{array}$ & Bankscope \\
\hline LTA & $\begin{array}{l}\text { Loans to Total } \\
\text { Assets ratio }\end{array}$ & Net Loans / Total Assets $(* 100)$ & Bankscope \\
\hline \multirow[t]{2}{*}{ LLPL } & $\begin{array}{l}\text { Loan Loss } \\
\text { Provisions to }\end{array}$ & Loan Loss Provisions / Gross Loans & Bankscope \\
\hline & $\begin{array}{l}\text { Gross Loans } \\
\text { ratio }\end{array}$ & & \\
\hline \multirow[t]{2}{*}{ TEATA } & $\begin{array}{l}\text { Total Earning } \\
\text { Assets to }\end{array}$ & Total Earning Assets / Total Assets & Bankscope \\
\hline & Total Assets ratio & & \\
\hline MS & Market & Bank Total Assets / Total Assets of the Banking & Bankscope; OECD \\
\hline
\end{tabular}




\begin{tabular}{|c|c|c|c|}
\hline & Share & Industry (country) & \\
\hline CR5 & $\begin{array}{l}\text { 5-bank } \\
\text { Concentration } \\
\text { ratio }\end{array}$ & $\begin{array}{l}\text { Market share (of total assets) of the } 5 \text { largest banks } \\
\text { (country) }\end{array}$ & Bankscope; OECD \\
\hline GDP & & Gross Domestic Product at current market prices & $\begin{array}{l}\text { European } \\
\text { Commission }\end{array}$ \\
\hline GDPG & & $\begin{array}{l}\text { Gross Domestic Product (1995 market prices) Growth } \\
\text { rate }\end{array}$ & $\begin{array}{l}\text { European } \\
\text { Commission }\end{array}$ \\
\hline GDPPC & & Per Capita Gross Domestic Product (pps) & $\begin{array}{l}\text { European } \\
\text { Commission }\end{array}$ \\
\hline INF & Inflation rate & $\begin{array}{l}\text { Annual percentage change of the Consumer Price } \\
\text { Index }\end{array}$ & $\begin{array}{l}\text { European } \\
\text { Commission }\end{array}$ \\
\hline UR & & $\begin{array}{l}\text { Unemployment rate (Eurostat definition }-\% \text { of } \\
\text { civilian active population) }\end{array}$ & $\begin{array}{l}\text { European } \\
\text { Commission }\end{array}$ \\
\hline \multirow[t]{6}{*}{ NSTIR } & $\begin{array}{l}\text { Nominal } \\
\text { Domestic }\end{array}$ & 3-month interbank rate (DK, SP, IT, NL, P, UK) & $\begin{array}{l}\text { European } \\
\text { Commission }\end{array}$ \\
\hline & $\begin{array}{l}\text { Short-term } \\
\text { Interest rate }\end{array}$ & 3-month treasury certificates (B) & $\begin{array}{l}\text { European } \\
\text { Commission }\end{array}$ \\
\hline & & $\begin{array}{l}\text { 3-month sale and repurchase agreements on private } \\
\text { sector paper (FR) }\end{array}$ & $\begin{array}{l}\text { European } \\
\text { Commission }\end{array}$ \\
\hline & & $\begin{array}{l}\text { 3-month interbank rate (until 1994) + 3-month Vibor } \\
\text { (GER) }\end{array}$ & $\begin{array}{l}\text { European } \\
\text { Commission }\end{array}$ \\
\hline & & 3-month Helibor (FIN) & $\begin{array}{l}\text { European } \\
\text { Commission }\end{array}$ \\
\hline & & 3-month Stibor (SW) & $\begin{array}{l}\text { European } \\
\text { Commission }\end{array}$ \\
\hline \multirow[t]{2}{*}{ ISTIR } & $\begin{array}{l}\text { Nominal } \\
\text { International }\end{array}$ & Treasury bill rate (USA) & IMF \\
\hline & $\begin{array}{l}\text { Short-term } \\
\text { Interest rate }\end{array}$ & & \\
\hline \multirow[t]{11}{*}{ NSTIRV } & NSTIR volatility & s.d. of the daily NL interbank 1-month offered rate & Datastream \\
\hline & & s.d. of the daily NOR interbank 3-month middle rate & Datastream \\
\hline & & s.d. of the daily SW interbank 1-month rate & Bloomberg \\
\hline & & s.d. of the daily UK interbank 1-month offered rate & Datastream \\
\hline & & s.d. of the daily Bank of Portugal interest rates & Bank of Portugal \\
\hline & & s.d. of the daily IT Euro-Lire 1-month rate & Datastream \\
\hline & & s.d. of the daily FR Euro-Frank 1-month rate & Datastream \\
\hline & & s.d. of the daily SP 15-day rate & Bloomberg \\
\hline & & s.d. of the daily DK Euro-Krone 1-month rate & Datastream \\
\hline & & s.d. of the daily GER Interbank 12-month offered rate & Datastream \\
\hline & & s.d. of the daily B Euro-Frank 1-month rate & Datastream \\
\hline ISTIRV & ISTIR volatility & s.d. of the USA interbank 1-month offered rate & Datastream \\
\hline \multirow[t]{2}{*}{ NEER } & Nominal Effective & $\begin{array}{l}\text { Performance relative to the rest of } 22 \text { industrialized } \\
\text { countries: }\end{array}$ & $\begin{array}{l}\text { European } \\
\text { Commission }\end{array}$ \\
\hline & Exchange rate & double export weights (base 1991=100) & \\
\hline REER & $\begin{array}{l}\text { Real Effective } \\
\text { Exchange rate }\end{array}$ & NEER*TTI & Own calculation \\
\hline TTI & & $\begin{array}{l}\text { Termos of Trade of goods and services (index } \\
1995=100 \text { ) }\end{array}$ & $\begin{array}{l}\text { European } \\
\text { Commission }\end{array}$ \\
\hline RES & & Official Reserves (excluding gold) & IMF \\
\hline RESG & & RES growth rate & Own calculation \\
\hline BTC & & $\begin{array}{l}\text { Balance of Current Transactions (with the rest of the } \\
\text { world) }\end{array}$ & $\begin{array}{l}\text { European } \\
\text { Commission }\end{array}$ \\
\hline $\mathrm{M} 2 \mathrm{G}$ & & Money (M2) growth rate & $\begin{array}{l}\text { European } \\
\text { Commission }\end{array}$ \\
\hline BFR & Banking Freedom & 6 - banking freedom index of the Heritage foundation & Heritage Foundation \\
\hline & & (average for the 1995-99 period) & \\
\hline
\end{tabular}




\section{Macrothink}

International Finance and Banking

ISSN 2374-2089

2018, Vol. 5, No. 1

\begin{tabular}{|c|c|c|c|}
\hline AREST & $\begin{array}{l}\text { Activity } \\
\text { Restrictions }\end{array}$ & $\begin{array}{l}\text { Sum of the Survey of Bank Regulation and } \\
\text { Supervision, questions } 4.1 \text { through }\end{array}$ & World Bank \\
\hline & & $\begin{array}{l}4.4 \text { (The methodology of Dermiguç-Kunt, Laeven } \\
\text { and Levine, 2004, was used) }\end{array}$ & \\
\hline \multirow[t]{2}{*}{ ST } & Stocks Traded & Volume of Stocks Traded / GDP (\%) & $\begin{array}{l}\text { World Development } \\
\text { Indicators, }\end{array}$ \\
\hline & & & World Bank \\
\hline $\begin{array}{l}\text { VOLDE } \\
\text { MMN }\end{array}$ & $\begin{array}{l}\text { Exchange rate } \\
\text { volatility }\end{array}$ & $\begin{array}{l}\text { s.d. of the monthly exchange rate agains the german } \\
\text { mark }\end{array}$ & IMF, own calculation \\
\hline NORD & Dummy variable & Equal to 1 if the country is SW, FIN, DK, NOR & Own calculation \\
\hline PTSPIT & Dummy variable & Equal to 1 if the country is PT, SP, IT & Own calculation \\
\hline \multirow[t]{2}{*}{ DCFPS } & Dummy variable & $\begin{array}{l}\text { Equal to } 1 \text { if the country is PT and the year is } 1992 \\
\text { and beyond, }\end{array}$ & Own calculation \\
\hline & & or the country is SP and the year is 1993 and beyond & \\
\hline $\begin{array}{l}\text { CRISP9 } \\
4\end{array}$ & Dummy variable & $\begin{array}{l}\text { Equal to } 1 \text { if the year is } 1992 \text { or } 1993 \text { (all countries), } \\
\text { or } 1994 \text { and the country is PT }\end{array}$ & Own calculation \\
\hline
\end{tabular}

\section{Copyrights}

Copyright for this article is retained by the author(s), with first publication rights granted to the journal.

This is an open-access article distributed under the terms and conditions of the Creative Commons Attribution license (http://creativecommons.org/licenses/by/4.0/) 